\title{
ANALISIS FAKTOR-FAKTOR YANG MEMPENGARUHI TINGKAT RISIKO AUDIT YANG DAPAT DITERIMA
}

\author{
Marsellisa Nindito \\ Fakultas Ekonomi, Universitas Negeri Jakarta \\ lisa_nindito@yahoo.com
}

\begin{abstract}
This research aims to analyze factors that influence the acceptable level of audit risk: a study conducted on auditors in East Jakarta. Those factors to be studied as the independent variables of this research are the risk of engagement $(X 1)$, the reliance level of external users of clients' financial statements (X2), the probability of client's financial difficulties (X3), and management integrity (X4). The data used in this research is primary data collected from the samples: 100 auditors working in public accountant offices in East Jakarta. The analysis of regression is applied to test the four hypotheses of the research using t-test and $F$ test. The results indicated thatthe risk of engagement (X1) with a significance value of the $t$-test of 0,000 and management integrity (X4) with a significance value of the t-test of 0,000 have effect on the acceptable level of audit risk corporate value while the reliance level of external users of clients' financial statements (X2) and the probability of client's financial difficulties (X3) have no effect on the acceptable level of audit risk.
\end{abstract}

Keyword: The acceptable level of audit risk, the risk of engagement, the reliance level of external users of clients' financial statements, the probability of client's financial difficulties, and management integrity. 


\section{PENDAHULUAN}

Dalam IDX Statistical Highlight, Fact Book, 2013 per kuartal pertama 2013 yang dikeluarkan oleh Bursa Efek Indonesia (BEI), disajikan fakta mengenai peningkatan signifikat terkait jumlah perusahaan yang terdaftar di BEI. Data menampilkan bahwa perusahaan yang terdaftar di BEI adalah sebanyak 383 di tahun 2007. Data ini kemudian bertambah sebanyak 13 perusahaan (menjadi 396) di tahun 2008 dan hanya 2 (menjadi 398) di tahun 2009. Setelah berlalunya krisis terlihat peningkatan signifikan jumlah perusahaan yang terdaftar yaitu sebanyak 420 perusahaan di tahun 2010 dan meningkat menjadi 440 di tahun 2011 dan 464 di kuartal pertama 2013. Saham terdaftar (dalam ribuan lembar) juga memperlihatkan peningkatan kapita-lisasi modal yang signifikan.Data menampilkan peningkatan nilai dua kali lipat dari sebesar 1128, 174 (2007) menjadi 1894, 828 (2010) menjadi 2491,781 (kuartal pertama 2013).

Data statistik di atas menampilkan perkembangan kuantitas dari perusahaan publik di Indonesia. Implikasi lebih lanjut dari data diatas menunjukkan semakin pentingnya penyajian laporan keuangan yang wajar dari pihak perusahaan kepada pihak investor yang menanamkan dana didalam perusahaan publik terkait. Perlindungan pemerintah Indonesia bagi para investor digulirkan dalam bentuk regulasi yang mensyaratkan keharusan penerbitan laporan keuangan tahunan yang teraudit bagi perusahaan perusahaan terdaftar di bursa ini selambatlambatnya 90 hari sejak akhir tahun buku perusahaan. Peran auditor sebagai pihak ketiga yang akan menurunkan risiko informasi bagi pihak pemilik perusahaan pun semakin diandalkan dalam kondisi ini. Pihak auditor lah yang merupakan pihak ketiga independen yang akan memberikan tambahan kredibilitas dan reabilitas laporan keuangan perusahaan yang terdaftar di bursa efek ini. Informasi mengenai kewajaran penyajian laporan keuangan ini berpotensi menguntungkan baik pemilik maupun manajer. Walaupun audit laporan keuangan hanya merupakan satu bentuk kemungkinan tambahan pengawasan, dalam praktisnya audit juga merupakan alat monitor yang efektif dan efisien. Auditor dalam hal ini memainkan peran yang penting dalam memonitor hubungan kontrak antara entitas dan pemegang saham, manajer, pegawai, dan pemberi utang. Hal tersebut meningkatkan pentingnya hasil audit yang berkualitas bagi para pemakai informasi audit. Lebih lanjut, Standar Profesional Akuntan Publik merupakan pedoman wajib bagi auditor dalam perencanaan dan pelaksanaan audit atas laporan keuangan.

Beberapa kasus fenomenal dalam dunia akuntansi di tahun 1990an seperti kasus Enron, WorldCom, Tyco, menunjukkan peran penting auditor atas laporan keuangan yang diauditnya. Opini 
mengenai kewajaran yang dikeluarkan oleh auditor merupakan hasil dari proses pengauditan dalam bentuk pelaksanaan prosedur audit yang dilakukan untuk mengumpulkan bukti-bukti pendukung opini. Luas, jenis dan waktu prosedur audit yang akan dilakukan auditor akan sangat tergantung pada tingkat risiko yang ditetapkan oleh auditor. Salah satu risiko yang akan ditetapkan oleh auditor dalam proses pengukuran risiko adalah tingkat risiko audit yang dapat diterima. Risiko audit merupakan risiko bahwa auditor salah memberikan opini atas laporan keuangan yang diaudit. Dalam hal ini, risiko audit didefinisikan sebagai risiko atau kemungkinan bahwa auditor memberikan opini wajar tanpa pengecualian pada laporan keuangan yang mengandung salah saji material. Risiko audit menjadi hal penting untuk dipertimbangkan oleh audit agar pengguna laporan keuangan tidak tersesat dalam pengambilan keputusan investasinya.

Risiko lain yang harus dipertimbangkan oleh auditor dalam konteks pertimbangan risko audit adalah risiko perikatan. Pada saat kantor akuntan publik setuju untuk menerima suatu tugas dalalam perikatan, saat itulah mereka terekspos dengan risiko berupa publisitas negatif bahkan lebih jauh lagi bisa berupa tuntutan hukum dari pihak-pihak yang merasa dirugikan. Risiko perikatan ini erat sekali kaitannya dengan risiko audit berupa risiko yang ditanggung oleh auditor karena salah menyatakan pendapat atas laporan keuangan yang diauditnya. Tingkat ketergantungan pengguna eksternal laporan keuangan juga merupakan salah satu faktor yang harus dipertimbangkan auditor dalam penetapan tingkat risiko audit yang dapat diterima. Arens et al menyatakan bahwa ketika pengguna ekternal sangat mengandalkan laporan keuangan, maka sangat tepat bagi auditor untuk menurunkan tingkat risiko audit yang dapat diterima. Hal ini disebabkan karena adanya peningkatan masalah sosial yang besar jika salah saji yang material tidak terdeteksi dalam laporan keuangannya. Tingkat ketergantungan ini dapat dilihat dari ukuran klien, distribusi kepemilikan serta sifat dan jumlah liabilitas yang ditanggung oleh manajemen perusahaan (J. Elder, 2011).

Hal lain yang harus dipertimbangkan oleh auditor dalam penentuan tingkat risiko audit yang dapat diterima adalah kemungkinan klien mengalami kesulitan keuangan setelah laporan keuangan diterbitkan. Kemungkinan kesulitan keuangan dapat dilihat dari posisi likuiditas, laba (rugi) yang dihasilkan perusahaan, metode pertumbuhan pembiayaan dan sifat kegiatan operasi klien. Terdapat kecenderungan umum terkait dengan hal ini adalah kemungkinan munculnya tuntutan hukum terhadap auditor yang dianggap gagal melakukan audit yang memadai atas laporan keuangan perusahaan terkait dan juga motif pemakai laporan 
keuangan untuk memperoleh kembali kerugian yang ditanggungnya karena penurunan nilai saham perusahaan. Hal ini terkait erat dengan risiko perikatan yang telah dibahas diatas.

Integritas manajemen merupakan salah satu pemicu konflik dalam kegiatan pengauditan.Moral hazard pihak manajemen untuk mendapatkan opini yang baik atas laporan keuangannya. Auditor akan perlu mengamati tingkat integritas manajemen dalam kegiatan bisnis perusahaan. Manajemen dengan integritas rendah akan mempengaruhi penetapan tingkat risiko yang dapat diterima oleh auditor dalam pelaksanaan penugasan audit.

Sejalan dengan meningkatnya kompleksitas informasi akuntansi yang diterapkan dalam kegiatan operasional perusahaan, terjadi peningkatan kompleksitas proses pengauditan bagi auditor. Sehingga hal ini akan juga memerlukan pertimbangan risiko audit yang tepat oleh auditor sebagai dasar penting dalam perencanaan kegiatan pengauditan nantinya. Dalam konteks ini, tingkat risiko audit yang dapat diterima akan menentukan tingkat risiko deteksi auditor atas salah saji yang mungkin terjadi dalam laporan keuangan yang diaudit. Dalam hal ini, auditor mengendalikan tingkat risiko auditnya dengan efektivitas dan luas dari audit yang dikerjakan. Semakin efektif dan luas audit yang dikerjakan (dan biaya audit yang lebih mahal), semakin kurang risiko salah saji akan tidak terdeteksi dan bahwa auditor akan menerbitkan laporan yang tidak tepat.Penjelasan diatas merupakan latar belakang yang mendasari diangkatnya penelitian ini yang akan menganalisa faktor-faktor yang mempengaruhi tingkat risiko audit yang dapat diterima. Berdasarkan latar belakang di atas, maka dapat dirumuskan pertanyaan penelitian sebagai berikut:

1. Apakah risiko perikatan berpengaruh terhadap tingkat risiko audit yang dapat diterima?

2. Apakah tingkat ketergantungan Pengguna eksternal laporan keuangan berpengaruh terhadap tingkat risiko audit yang dapat diterima?

3. Apakah kemungkinan kesulitan keuangan klien berpengaruh terhadap tingkat risiko audit yang dapat diterima?

4. Apakah integritas manajemenberpengaruh terhadap tingkat risiko audit yang dapat diterima

\section{KAJIAN PUSTAKA}

Saat kantor akuntan publik setuju untuk menerima suatu tugas dalalam perikatan, saat itulah KAP tersebut akan terekspos dengan risiko berupa publisitas negatif dan tuntutan hukum dari pihak-pihak yang merasa dirugikan. Risiko perikatan adalah risiko yang ditanggung oleh auditor atau KAP berupa kemungkinan timbulnya masalah setelah pekerjaan audit selesai dilakukan, meskipun laporan 
opini audit yang dikeluarkan seudah benar. Risiko perikatan terkait erat dengan risiko audit sebagai tingkat risiko yang ditanggung oleh auditor karena salah menyatakan pendapat atas laporan keuangan yang diauditnya. Risiko perikatan (engagementrisk) menurut Messier adalah risiko yang berhubungan dengan eksposur auditor terhadap kerugian dan kerusakan financial atau pencemaran praktik profesionalnya karena litigasi, publikasi yang buruk, dan peristiwaperistiwa lain yang timbul yang berhubungan dengan laporan keuangan yang diaudit dan dilaporkan. Auditor yang telah melaksanakan audit sesuai dengan standar audit yang berlaku umum, namun audit tersebut masih bisa dituntut oleh klien atau pihak ketiga. Meskipun auditor telah mematuhi standard dan memenangkan tuntutan hukum itu, reputasi profesionalnya telah tercemar dalam proses itu karena publikasi yang negatif (Messier, 2008). Arens et al menjelaskan risiko kontrak kerja sebagai risiko dimana auditor atau KAP akan mendapat mendapatkan masalah setelah audit diselesaikan, meskipun laporan audit sudah benar. Dijelaskan lebih lanjut oleh Arens bahwa risiko kontrak kerja akan sangat terkait dengan risiko bisnis klien (J. Elder, 2011). M.Guy et.al (2002) menjelaskan bahwa tahap awal dalam audit laporan keuangan adalah mengambil keputusan untuk menerima atau menolak suatu kesempatan menjadi auditor untuk klien baru atau untuk melanjutkan sebagai auditor bagi klien yang sudah ada. Kantor akuntan tidak memiliki kewajiban setiap calon begitu saja. Auditor harus mengevaluasi apakah penerimaan atau melanjutkannya sebagai klien akan menambah risiko bisnis auditor atau sebaliknya merusak reputasi dan citra kantor akuntan. Lebih lanjut juga dijelaskan oleh Tuanakota, bahwa dalam hal penerimaan klien, ancaman kepentingan pribadi terhadap kompetensi dan sikap kecermatan dan kehati-hatian profesional dapat terjadi ketika tim perikatan tidak memiliki kompetensi yang diperlukan. Tingkat risiko audit akan berbeda-beda diantara auditor/KAP yang berbeda. Hal ini akan ditentukan oleh tingkat penerimaan auditor/KAP atas kemungkinan bahwa mereka gagal memodifikasi opini mereka pada laporan keuangan yang mengandung salah saji material (Tuanakotta, 2011). Karena itu hipotesis pertama penelitian ini adalah:

H1: Risiko perikatan berpengaruh terhadap tingkat risiko audit yang bisa diterima

Tuanakota et al menyatakan bahwa laporan keuangan adalah media utama bagi entitas untuk mengkomunikasikan informasi manajemen oleh manajemen kepada pemangku kepentingan (Tuanakotta, 2011). Berdasarkan peratur-an dari Bapepam LK no X.K.6 selaku badan pengawas pasar modal di Indonesia, perusahaan 
publik disyaratkan untuk melaporkan laporan tahunannya. Laporan tahunan yang disampaikan adalah berupa laporan keuangan dan juga informasi lain seperti diskusi dan analisa manajemen dan informasi relevan lainnya. Tingkat ketergantungan pemakai laporan keuangan merupakan salah satu faktor yang dapat dipertimbangkan oleh auditor pada penentuan tingkat risiko audit yang dapat diterima

Semakin besar kegiatan operasi klien maka semakin luas penggunaan laporan keuangan entitas tersebut. Sehingga dalam hal ini semakin besar ukuran perusahaan maka akan semakin besar tingkat ketergantungan pemakai laporan keuangan. Demikian pula dengan dengan bentuk kepemilikan perusahaan. Laporan keuangan perusahaan publik akan lebih banyak dipakai dan diandalkan oleh pihak-pihak yang berkepentingan dibandingkan perusahaan yang kepemilikannya tertutup atau privat. Lebih lanjut dalam penelitian ini semakin besar persentase kepemilikan publik dalam perusahaan maka akan menunjukkan semakin besarnya tingkat ketergantungan pemakai laporan keuangan atas entitas terkait. Satu hal lagi yang dibahas dalam penelitian ini yaitu jumlah liabilitas perusahaan. Dalam arti, jumlah liabilitas yang besar mencerminkan besarnya ketergantungan para kreditor dan calon kreditor atas laporan keuangan entitas terkait. Arens et al menyatakan bahwa ketika pengguna eksternal sangat mengandalkan laporan keuangan maka sangat tepat untuk menurunkan risiko audit yang dapat diterimaBerdasarkan penjelasan diatas maka hipotesis penelitian yang kedua adalah:

H2: Tingkat ketergantungan Pengguna eksternal laporan keuangan berpengaruh terhadap tingkat risiko audit yang dapat diterima (J. Elder, 2011).

Arens et al menjelaskan jika klien terpaksa mengumumkan kebangkrutannya atau mengalami kerugian yang sangat besar setelah dilaksanakan, auditor akan menghadapi kemungkinan yang lebih besar untuk mempertahankan kualitas auditnya dibandingkan jika klien tidak menghadapi kesulitan keuangan. Lebih lanjut, faktor lain yang dapat dipertimbangkan auditor/KAP dalam penentuan tingkat risiko audit yang dapat diterima adalah kemungkinan kegagalan keuangan perusahaan. Auditor/KAP akan menghadapi tantangan lebih besar dalam mengaudit perusahaan dengan masalah keuangan dibandingkan perusahaan yang berjalan secara profitable. Sehingga untuk mempertahankan kualitas audit yang sama, maka auditor akan lebih berhati hati dalam penentuan tingkat risiko audit yang dapat diterimanya agar kualitas audit dapat dipertahankan. Tingkat likuiditas perusahaan dan perubahan laba/rugi perusahaan akan mencerminkan kondisi keuangan perusahaan. Kedua faktor ini akan mencerminkan kemampuan 
perusahaan dalam melunasi liabilitasnya. Faktor lainnya adalah pertumbuhan pembiayaan perusahaan yang dilihat dari besarnya jumlah liabilitas jangka pendek disbanding dengan liabilitas jangka panjangnya. Faktor ini digunakan sebagai evaluasi atas risiko kegagalan keuangan jika kegiatan operasi klien mengalami penurunan. Faktor terakhir yang mencerminkan kesulitan keuangan perusahaan adalah sifat kegiatan operasi klien (J. Elder, 2011). Dalam hal ini, perusahaan yang beroperasi pada industri atau tahap tertentu secara alami atau bawaan akan lebih berisiko dibanding perusahaan lainnyaPenjelasan diatas membentuk hipotesis ketiga penelitian ini yaitu:

H3: Kemungkinan kesulitan keuangan klien berpengaruh terhadap tingkat risiko audit yang dapat diterima

Integritas manajemen merupakan salah satu pemicu konflik dalam kegiatan pengauditan.Moral hazard dapat muncul pada pihak manajemen yang disebabkan oleh keinginan untuk mendapatkan opini yang baik atas laporan keuangannya. Manajemen dengan integritas rendah akan mempengaruhi penetapan tingkat risiko yang dapat diterima oleh auditor dalam pelaksanaan penugasan audit. Vincent J. Love and Thomas R. Manisero (2011) menyatakan bahwa integritas manajemen merupakan faktor kunci dalam efikasi kegiatan audit yang dilakukan sesuai dengan
Generally accepted auditing standards (GAAS) as practiced in theUnited States. Arens menjelaskan bahwa perusahaan perusahan dengan integritas yang rendah terjadi apabila perusahaan menjalankan aktivitas bisnis mereka dengan cara-cara yang dapat menimbulkan konflik dengan para pemegang saham, pemerintah dan pelanggannya (J. Elder, 2011). Konflik-konflik terse-but kemudian akan tercermin dalam persepsi pengguna laporan keuangan terhadap kualitas audit dan juga dapat mengakibatkan tuntutan hukum dan hal lainnya. Tuanakota menjelaskan bahwa KAP harus merumuskan kebijakan dan prosedur pengen-dalian mutu untuk menentukan apakah perikatan dari klien akan diterima atau dilanjutkan untuk meminimumkan terjadinya hubung-an dengan klien yag tidak memiliki integritas (Tuanakotta, 2011). Adanya keharusan bagi KAP dalam menetapkan prosedur untuk tujuan tersebut, tidak berarti bahwa KAP bertugas untuk menentukan integritas atau keandalan klien dan tidak juga bahwa KAP berkewajiban kepada siapapun kecuali pada dirinya untuk menerima, menolak atau memperta-hankan kliennya. Namun berda-sarkan prinsip pertimbangan kehati-hatian (prudence) KAP disarankan selektif dalam menentukan hubungan profesionalnya. Arens menjelaskan lebih lanjut bahwa kegiatan menyelidiki klien baru dan mengevaluasi klien lama merupakan bagian yang penting dalam 
menentukan risiko audit yang dapat diterima (J. Elder, 2011). Timothy G. Kizirian, Brian W. Mayhew, L. Dwight Sneathen, Jr (2011) menyatakan terdapat hubungan terbalik antara integritas manajemen dengan kemungkinan pedeteksian salah saji. Hipotesis keempat dalam penelitian ini adalah:

$\mathrm{H} 4$ : Integritas manajemen berpengaruh terhadap tingkat risiko audit yang dapat diterima

Kerangka pemikiran dalam penelitian ini dapat digambarkan sebagai berikut:

Bagan 1. Kerangka pemikiran

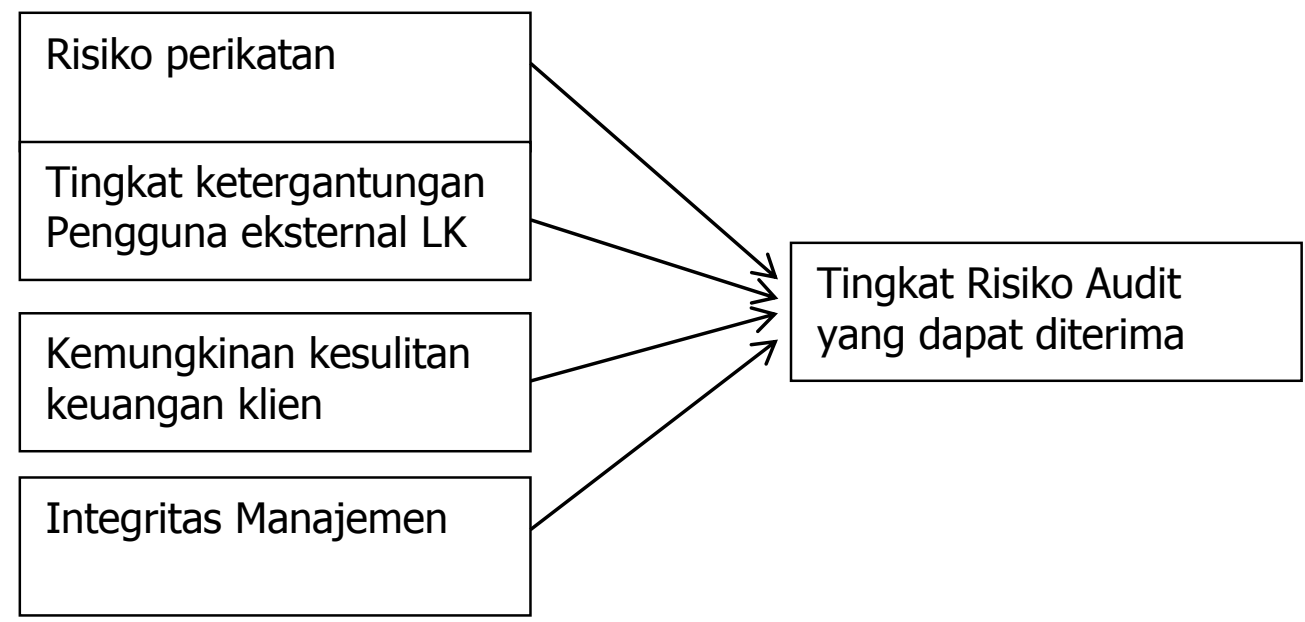

\section{METODE PENELITIAN}

Metode yang digunakan dalam penelitian ini adalah metode kuantitatif dengan menggunakan pendekatan regresi linear berganda. Penelitian dilakukan dengan menggunakan data primer yang diperoleh dengan menyebarkan kuesioner kepada responden. Sumber data dalam penelitian ini adalah skor dari masing-masing indikator variabel yang diperoleh dari kuesioner yang telah diisi oleh auditor yang bekerja pada KAP di Jakarta Timur sebagai responden. Operasionalisasi Variabel Penelitian Variabel Dependen (Tingkat risiko audit yang dapat diterima)
Tingkat risiko audit yang dapat diterima adalah tingkat kesediaan auditor untuk menerima kemungkinan adanya salah saji dalam laporan keuangan setelah audit telah selesai dijalankan dan opini wajar tanpa pengecualian telah diterbitkan. Pengukuran variabel ini menggunakan tiga indikator risiko audit yaitu: 1) Risiko Bawaan (Inherent risk), 2) Risiko Pengendalian (Control Risk), 3) Risiko Deteksi (Detection Risk).

Variabel independen dalam penelitian ini yaitu risiko perikatan, tingkat ketergantungan Pengguna eksternal laporan keuangan, 
kemungkinan kesulitan keuangan klien, dan integritas manajemen.

a. Risiko Perikatan

Risiko perikatan adalah risiko dimana auditor atau KAP akan mendapatkan masalah setelah audit selesai dilakukan. Risiko Perikatan dalam penelitian ini diukur dengan 3 indikator berupa: 1) investigasi klien baru dan mengevaluasi klien lama, 2) Mengidentifikasi alasan klien untuk melakukan audit dan 3) mendapatkan kesepahaman dengan klien.

b. Tingkat ketergantungan Pengguna eksternal laporan keuangan

Tingkat ketergantungan

Pengguna eksternal laporan keuangan adalah tingkat ketergantungan dari pengguna laporan keuangan akan kewajaran penyajian laporan keuangan perusahaan sebagai dasar pengambilan keputusan ekonomis. Dalam penelitian ini terdapat 3 indikator yang digunakan dalam mengukur tingkat ketergantungan Pengguna eksternal laporan keuangan yaitu: ukuran klien, distribusi kepemilikan, dan sifat dan jumlah liabilitas yang dimiliki perusahaan.

\section{c. Kemungkinan kesulitan keuangan} klien.

Kemungkinan kesulitan keuangan klien adalah kemungkinan kesulitan keuangan yang dialami oleh klien audit. Dalam penelitian ini kemungkinan kesulitan keuangan klien diukur dengan 5 indikator yaitu: 1) posisi likuiditas, 2) laba/ rugi ditahun tahun sebelumnya, 3 ) metode pertumbuhan pembayaran, 4) Sifat kegiatan operasi klien, dan 5) Kompetensi manajemen.

d. Integritas Manajemen Integritas manajemen merupakan ukuran pelaksanaan strategi perusahaan oleh manajemen dalam bentuk aktivitas bisnis yang tidak menimbulkan konflik dengan pemegang kepentingan. Dalam penelitian ini diukur dengan 1) Filosofi manajemen dan gaya kepemimpinan, 2) kemampuan manajemen mengidentifikasi dan menghadapi risiko, dan 3) penerapan tata kelola perusahaan yang baik berupa struktur organisasi yang efektif dan aktivitas dewan direksi dan komite auditnya.

Populasi yang digunakan dalam penelitian ini para auditor di wilayah Jakarta Timur. Sampel dalam penelitian ini sejumlah 100 orang auditor yang berpraktik di Jakarta Timur yang bisa mengisi kuisoner penelitian yang disebarkan peneliti.

Data dikumpulkan dengan menggunakan metode survei, yaitu dengan merekam hasil pengisian kuisoner penelitian. Sumber data dalam penelitian ini adalah skor dari masing-masing indikator variabel yang diperoleh dari kuesioner yang telah diisi oleh auditor yang bekerja pada KAP di Jakarta Timur sebagai responden. 
Tabel 1. Kisi-kisi indikator kuisoner penelitian

\begin{tabular}{|c|c|c|}
\hline Variabel & Sumber & Indikator \\
\hline Risiko Audit & $\begin{array}{l}\text { Messier, } \\
2008\end{array}$ & $\begin{array}{l}\text { a. Risiko Bawaan } \\
\text { b. Risiko Pengendalian } \\
\text { c. Risiko Deteksi }\end{array}$ \\
\hline Risiko Perikatan & $\begin{array}{l}\text { Arens, } \\
2011\end{array}$ & $\begin{array}{l}\text { a. investigasi klien baru dan mengevaluasi klien } \\
\text { lama } \\
\text { b. Mengidentifikasi alasan klien untuk } \\
\text { melakukan audit } \\
\text { c. mendapatkan kesepahaman dengan klien }\end{array}$ \\
\hline $\begin{array}{l}\text { Tingkat } \\
\text { ketergantungan } \\
\text { pemakai laporan } \\
\text { keuangan } \\
\end{array}$ & $\begin{array}{l}\text { Arens, } \\
2011\end{array}$ & $\begin{array}{l}\text { a. ukuran klien } \\
\text { b. distribusi kepemilikan } \\
\text { c. sifat dan jumlah liabilitas yang dimiliki } \\
\text { perusahaan. }\end{array}$ \\
\hline $\begin{array}{l}\text { Kemungkinan } \\
\text { Kesulitan } \\
\text { Keuangan Klien }\end{array}$ & $\begin{array}{l}\text { Arens, } \\
2011\end{array}$ & $\begin{array}{l}\text { a. posisi likuiditas } \\
\text { b. laba/rugi ditahun tahun sebelumnya } \\
\text { c. metode pertumbuhan pembayaran } \\
\text { d. Sifat kegiatan operasi klien } \\
\text { e. Kompetensi manajemen }\end{array}$ \\
\hline $\begin{array}{l}\text { Integritas } \\
\text { manajemen }\end{array}$ & $\begin{array}{l}\text { Arens, } \\
2011\end{array}$ & $\begin{array}{l}\text { a. Filosofi manajemen dan gaya kepemimpinan } \\
\text { b. kemampuan manajemen mengidentifikasi dan } \\
\text { menghadapi risiko } \\
\text { c. penerapan tata kelola perusahaan yang baik } \\
\text { berupa struktur organisasi yang efektif dan } \\
\text { aktivitas dewan direksi dan komite auditnya. }\end{array}$ \\
\hline
\end{tabular}

Sumber: Data diolah sendiri (2014)

Metode analisa data yang digunakan dalam penelitian ini adalah metode kuantitatif dengan menggunakan pendekatan regresi linear berganda.

\section{HASIL DAN PEMBAHASAN}

Hasil Pengujian Kualitas Data

Uji validitas dilakukan dengan melakukan korelasi bivariate (spearman correlation) antara masingmasing skor indikator dengan total skor konstruk. Pengujian validitas dilakukan dengan 19 responden, yaitu auditor yang bekerja pada KAP Amachi, Arifin, Mardani \& Mulyadidan KAP Bambang Sudaryono \& Rekan. Dengan menggunakan uji dua sisi (two-tailed) dan taraf signifikansi $5 \%$, maka nilai $r$ tabel dalam penelitian ini adalah 0.433. Item pertanyaan dinyatakan valid jika nilai $r$ hitung $>$ dari nilai $r$ tabel atau lebih besar dari 0,433. Hasil uji validitas menunjukkan bahwa 8 butir pernyataan variabel RP (X1) memiliki nilai $r$ hitung $>r$ 
tabel dan dinyatakan semua valid. Selanjutnya, untuk variabel TK $\left(\mathrm{X}_{2}\right)$, ketujuh butir pernyataan dinyatakan valid karena memiliki $r$ hitung $>r$ tabel. Demikian jugauntuk variabel KK $\left(X_{3}\right)$, terdapat kesembilan butir pernyataan dinyatakan valid karena memiliki $r$ hitung $>r$ tabel. Variabel IM ( $\left.X_{4}\right)$ yang terdiri ata 8 butir pernyataan juga dinyatakan valid karena memiliki $r$ hitung $>r$ tabel. Variabel dependen dalam penelitian ini, yaitu RA terdiri atas 15 butir, tetapi 4 diantaranya tidak valid yaitu butir $1,3,7,8$ yang memiliki nilai $r$ hitung < $r$ tabel, maka yang dinyatakan valid hanya 11 butir.

$\mathrm{Uji}$ reliabilitas dilakukan dengan uji cronbach alpha. Suatu konstruk dikatakan reliabel jika memberikan nilai cronbach alpha > 0,70 Hasil uji reliabilitas dapat dilihat dari Tabel 2 sebagai berikut:

Tabel 2. Hasil Uji Reliabilitas

\begin{tabular}{cccc}
\hline No. & Variabel & Nilai Cronbach Alpha & Kesimpulan \\
\hline 1 & RA & 0.809 & Reliabel \\
\hline 2 & RP & 0.890 & Reliabel \\
\hline 3 & TK & 0.777 & Reliabel \\
\hline 4 & KK & 0.868 & Reliabel \\
\hline 5 & IM & 0.780 & Reliabel \\
\hline
\end{tabular}

Sumber: Data diolah sendiri menggunakan SPSS 19 (2014)

Dari tabel di atas dapat dilihat bahwa nilai cronbach alpha untuk seluruh variabel di atas 0,70 sehingga dapat disimpulkan bahwa pernyataan yang mewakili variabelvariabel tersebut adalah reliabel.

Data Unit Analisis

Dari Tabel 2 dibawah ini, dapat diketahui bahwa dari 100 kuesioner yang dibagikan pada responden, 100 kuesioner (\%) kembali dan yang dapat diolah oleh peneliti. Tabel-tabel dibawah ini memberikan gambaran umum dari responden yang terdiri atas jenis kelamin, pendidikan terakhir, posisi atau jabatan responden, dan lamanya responden bekerja sebagai auditor.

Tabel 3. Tingkat Pengembalian Kuesioner

\begin{tabular}{lcc}
\hline \multicolumn{1}{c}{ Kuesioner } & Jumlah & Persentase \\
\hline Kuesioner yang dibagikan & 100 & 100 \\
\hline Kuesioner yang tidak kembali & 0 & 0 \\
\hline Kuesioner yang kembali & 100 & 100 \\
\hline Kuesioner yang tidak dapat diolah & 0 & 0 \\
\hline Kuesioner yang dapat diolah & 100 & 100
\end{tabular}

Sumber: Data diolah sendiri (2014) 
Tabel 4. Jenis Kelamin Responden

\begin{tabular}{cccc}
\hline No. & Jenis Kelamin & Jumlah & Persentase (\%) \\
\hline 1 & Pria & 46 & 46 \\
\hline 2 & Wanita & 35 & 35 \\
\hline 3 & Kosong & 19 & 19 \\
\hline & Jumlah & 100 & 100 \\
\hline
\end{tabular}

Sumber: Data diolah sendiri (2014)

Tabel $4 \mathrm{di}$ atas menunjukkan bahwa proporsi sampel auditor yang bekerja pada Kantor Akuntan Publik
(KAP) di wilayah Jakarta Timur auditor pria sebanyak 46 orang, dan auditor wanita sebanyak 35 orang.

Tabel 5. Pendidikan Terakhir Responden

\begin{tabular}{cccc}
\hline No. & Pendidikan Terakhir & Jumlah & Persentase $(\%)$ \\
\hline 1 & D3 & 14 & 14 \\
\hline 2 & S1 & 60 & 60 \\
\hline 3 & S2 & 2 & 2 \\
\hline 4 & Kosong & 24 & 24 \\
\hline & Jumlah & 100 & 100 \\
\hline
\end{tabular}

Sumber: Data diolah sendiri (2014)

Tabel 5 menunjukkan bahwa pendidikan terakhir yang dijalani auditor didominasi oleh tingkat pendidikan S1, yaitu sebanyak 60 orang $(60 \%)$. Kemudian yang telah menyelesaikan pendidikan S2 sebanyak 2 orang (2\%). Sementara itu, auditor yang berpendidikan terakhir D3 sebanyak 14 orang $(14 \%)$.

Dari hasil kuesioner yang diterima, dapat diketahui berapa lamanya pengalaman responden bekerja sebagai auditor, yaitu sebagai berikut:

Tabel 6. Pengalaman sebagai Auditor

\begin{tabular}{cccc}
\hline No. & $\begin{array}{c}\text { Pengalaman sebagai } \\
\text { Auditor }\end{array}$ & Jumlah & Persentase \\
\hline 1 & $0-2$ tahun & 30 & 30 \\
\hline 2 & $2-5$ tahun & 22 & 22 \\
\hline 3 & $5-10$ tahun & 13 & 13 \\
\hline 4 & $>10$ tahun & 1 & 1 \\
\hline 5 & Kosong & 34 & 34 \\
\hline \multicolumn{2}{c}{ Jumlah } & 100 & 100 \\
\hline
\end{tabular}

Sumber: Data diolah sendiri (2014) 
Tabel 6 menunjukkan bahwa responden yang baru memiliki pengalaman sebagai auditor $<2$ tahun sebanyak 30 orang (30\%). Sebanyak 22 orang (22\%) dari total responden memiliki pengalaman sebagai auditor selama 2-5 tahun, 13 orang $(13 \%)$ selama $5-10$ tahun dan 1 orang (1\%) selama lebih dari 10 tahun.

\section{Statistik Deskriptif}

\section{Tabel 7. Statistik Deskriptif}

Descriptive Statistics

\begin{tabular}{|l|r|r|r|r|r|r|}
\hline & $N$ & Minimum & Maximum & Sum & Mean & Std. Deviation \\
\hline Risiko Audit Yang Dapat & 100 & 21 & 50 & 4257 & 42.57 & 4.200 \\
Diterima & 100 & 16 & 37 & 3149 & 31.49 & 3.170 \\
Risiko Perikatan & 100 & 14 & 33 & 2582 & 25.82 & 2.664 \\
$\begin{array}{l}\text { Tingkat Ketergantungan } \\
\text { Pemakai Laporan }\end{array}$ & 100 & 19 & 42 & 3399 & 33.99 & 3.642 \\
Keuangan & 100 & 18 & 40 & 3170 & 31.70 & 3.224 \\
Kemungkinan Kesulitan & 100 & & & & & \\
Keuangan Klien & & & & & \\
IntegritasManajemen & & & & & \\
Valid N (listwise) & & & & & \\
\hline
\end{tabular}

Sumber: Data diolah sendiri menggunakan SPSS (2014)

Berdasarkan hasil analisis regresi dapat dituliskan model regresi sebagai berikut:

$\mathrm{RA}=4.578+0.756 \mathrm{RP}+0.141 \mathrm{TK}-$

$0.178 \mathrm{KK}+0.523 \mathrm{IM}+\mathrm{e}$
Hasil Uji -t Hasil uji-t ditunjukkan pada Tabel 8 berikut ini.

Tabel 8. Hasil Uji-t

Coefficients $^{a}$

\begin{tabular}{|c|c|c|c|c|c|c|}
\hline \multirow{2}{*}{\multicolumn{2}{|c|}{ Model }} & \multicolumn{2}{|c|}{ Unstandardized Coefficients } & \multirow{2}{*}{$\begin{array}{c}\begin{array}{c}\text { Standardized } \\
\text { Coefficients }\end{array} \\
\text { Beta }\end{array}$} & \multirow[b]{2}{*}{$\mathrm{t}$} & \multirow[b]{2}{*}{ Sig. } \\
\hline & & $\mathrm{B}$ & Std. Error & & & \\
\hline \multirow[t]{5}{*}{1} & (Constant) & 4.578 & 2.951 & & 1.551 & .124 \\
\hline & Risiko Perikatan & .756 & .111 & .571 & 6.790 & .000 \\
\hline & $\begin{array}{l}\text { Tingkat Ketergantungan } \\
\text { Pemakai Laporan } \\
\text { Keuangan }\end{array}$ & .141 & .130 & .089 & 1.084 & .281 \\
\hline & $\begin{array}{l}\text { Kemungkinan Kesulitan } \\
\text { Keuangan Klien }\end{array}$ & -.178 & .095 & -.154 & -1.867 & .065 \\
\hline & IntegritasManajemen & .523 & .098 & .402 & 5.333 & .000 \\
\hline
\end{tabular}

a. Dependent Variable: Risiko Audit Yang Dapat Diterima

Sumber: Data diolah sendiri menggunakan SPSS 19 (2014) 
Dari uji ANOVA diperoleh nilai $F$ hitung sebesar 50.856> 4 dengan tingkat signifikansi $0.000<0,05$.
Hal ini menunjukkan bahwa semua variabel dalam model persamaan regresi.

Tabel 9. Hasil Uji-F

ANOVA

\begin{tabular}{|ll|r|r|r|r|l|}
\hline Model & & \multicolumn{1}{|c|}{$\begin{array}{c}\text { Sum of } \\
\text { Squares }\end{array}$} & \multicolumn{1}{c|}{ df } & Mean Square & F & Sig. \\
\hline 1 & Regression & 1190.525 & 4 & 297.631 & 50.856 & $.000^{\mathrm{a}}$ \\
& Residual & 555.985 & 95 & 5.852 & & \\
& Total & 1746.510 & 99 & & & \\
\hline
\end{tabular}

a. Predictors: (Constant), Integritas Manajemen, Tingkat Ketergantungan Pemakai Laporan Keuangan, Kemungkinan Kesulitan Keuangan Klien, Risiko Perikatan

b. Dependent Variable: Risiko Audit Yang Dapat Diterima

Tabel 10. Koefisien Determinasi $\left(R^{2}\right)$

Model Summary

\begin{tabular}{|l|l|l|r|r|}
\hline Model & $\mathrm{R}$ & $\mathrm{R}$ Square & $\begin{array}{c}\text { Adjusted R } \\
\text { Square }\end{array}$ & $\begin{array}{c}\text { Std. Error of } \\
\text { the Estimate }\end{array}$ \\
\hline 1 & $.826^{\mathrm{a}}$ & .682 & .668 & 2.419 \\
\hline
\end{tabular}

a. Predictors: (Constant), Integritas Manajemen, Tingkat Ketergantungan Pemakai Laporan Keuangan, Kemungkinan Kesulitan Keuangan Klien, Risiko Perikatan

b. Dependent Variable: Risiko Audit Yang Dapat Diterima

Sumber: Data diolah sendiri menggunakan SPSS 19 (2014)

Hasil pengujian menunjukkan bahwa adjusted $\mathrm{R}^{2}$ sebesar 0.668 atau $66.8 \%$. Dengan demikian dapat disimpulkan risiko perikatan, tingkat ketergantungan pengguna LK, kemungkinan kesulitan keuangan klien, dan integritas manajemen mampu menjelaskan variabel tingkat risiko audit yang dapat diterima sebesar 0.668 atau sebesar $66.8 \%$. Sedangkan sisanya $33.2 \%$ dijelaskan oleh variabelvariabel lain yang tidak dibahas dalam penelitian ini.

\section{Pembahasan}

1. Pengaruh risiko perikatan terhadap tingkat risiko audit yang dapat diterima.

Pada pengujian hipotesis yang dilakukan dengan uji-t, diperoleh nilai t hitung 6,790 pada tingkat signifikansi 0,000 . Nilai ini menunjukkan bahwa risiko perikatan berpengaruh terhadap tingkat risiko audit yang dapat diterima. Sesuai dengan penjelasan Messier (2011) dalam pelaksanaan pemeriksaan laporan keuangan, auditor akan 
melakukan berbagai pengukuran dan dan menetapkan berbagai pertimbangan agar risiko audit dapat dikurangi pada level yang cukup rendah, yang menurur pertimbangan profesional auditor tepat untuk menyatakan pendapat atas laporan keuangan. Selain hal teknis terkait dengan pengukuran tingkat salah saji material yang mugkin terjadi dalam laporan keuangan klien, hal penting lain adalah pengukuran risiko perikatan yang akan ditanggung auditor pada saat perikatan tersebut diterima.

Berbeda dengan risiko audit yang dapat diterima, risiko perikatan yang berhubungan dengan eksposur auditor terhadap kerugian finansial dan juga rusaknya nama baik tidak dapat dikendalikan langsung oleh auditor. Oleh karena itu auditor akan sangat berhati-hati dan memberikan perhatian yang besar atas risiko perikatan ini dalam pertimbangan penerimaan klien baru atau meneruskan perikatan sebelumnya. Hal ini sesuai dengan pendapat dari Agoes \& Husada (2012) yang menyatakan bahwa pertimbangan mengenai risiko perikatan ini sangat relevan dengan isu pengendalian mutu KAP terkait dengan penerimaan dan keberlanjutan klien. Oleh karena itu, dalam pertimbangannya KAP harus berhati-hati atau prudence dan selektif dalam menentukan hubungan profesionalnya.

Pembuktian hipotesis satu ini sesuai dengan teori titik kritis auditor sebagaimana yang dijelaskan Tuanakota bahwa kondisi pasca audit, proses audit dan sumber daya manusia dari KAP merupakan tiga titik kritis yang harus dipertimbangkan dalam praktik audit. Titik kritis dalam kondisi pasca audit ini adalah titik kritis yang berhubungan dengan risiko perikatan berupa urusan hukum seperti gugatan dan tuntutan oleh penegak hukum dan pihak pihak yang merasa dirugikan. Sedangkan titik kritis proses audit erat kaitannya dengan penetapan tingkat risiko audit yang dapat diterima karena merupakan titik kritis yang bisa dikendalikan langsung oleh sang auditor. Skor setuju dan sangat setuju paling banyak diberikan pada butir pernyataan keenam yang mengangkat mengenai pertimbangan terkaitnya siapa pengguna laporan keuangan dalam relevansinya dengan risiko perikatan audit. Pihak yang menggunakan laporan keuangan akan merupakan menentukan tingkat eksposur auditor terhadap publisitas negatif dan tuntutan hukum.

Auditor sebagai pihak yang independen dalam hubungan antara manajemen dan pemegang saham serta pemegang kepentingan lain memberikan perhatian besar pada risiko perikatan dalam pertimbangan penentuan tingkat risiko audit yang dapat diterima. Hal ini untuk mendukung peran auditor dalam memberikan keyakinan memadai bagi para pemegang kepentingan terkait dengan laporan keuangan klien yang mereka audit. Hal ini didukung oleh hasil pengisian 
kuisoner oleh responden auditor Butir penyataan pertama dan kedua merupakan butir pertanyaan merupakan butir penyataan lain yang menerima respon terbanyak setuju dan sangat setuju. Responden menganggap penting pemahaman auditor akan kliennya sebagai usaha mengurangi risiko perikatan. Responden menganggap penting bahwa sebelum menerima klien baru, KAP harus mencari informasi mengenai calon kliennya seperti posisi klien dalam komunitas bisnis, hubungan dengan KAP sebelumnya, dan sebagainya. Responden juga sependapat bahwa auditorakan menetapkan risiko audit yang lebih tinggi pada klien baru yang merupakan perusahan baru didirikan tapi pertumbuhan bisnisnya sangat cepat (Tuanakotta, 2011).

2. Pengaruh tingkat ketergantungan pengguna eksternal LK terhadap tingkat risiko audit yang dapat diterima.

Pada pengujian hipotesis yang dilakukan dengan uji-t, diperoleh nilai $\mathrm{t}$ hitung 1,084 pada tingkat signifikansi 0,281. Hasil ini menunjukkan bahwa tingkat ketergantungan pengguna eksternal Lk tidak berpengaruh terhadap tingkat risiko audit yang dapat diterima. Hasil pengisian kuisoner yang menunjukkan bahwa besarnya total aset perusahaan yang merupakan indikator tingkat ketergantungan pengguna eksternal bukan merupakan pertimbangan penting bagi auditor dalam penentuan tingkat risiko audit. Lebih lanjut terkait dengan butir pernyataan ketiga, auditor juga tidak memberikan perhatian besar pada luas pengguna laporan keuangan klien serta pada besarnya liabilitas perusahaan yang notabene merupakan pihak pengguna eksternal laporan keuangan klien. Messier menyatakan bahwa risiko audit akan dipengaruhi oleh ukuran dan kompleksitas entitas, pengalaman dan pengetahuan auditor akan entitas dan lingkungannya (Messier, 2008). Tuanakota menyatakan bahwa auditor akan memusatkan upayanya pada kondisi-kondisi yang besar kemungkinan mengandung masalah dan/atau salah saji sehingga auditor hanya akan memberikan perhatian penuh dalam bentuk waktu, sumber daya dan sumber lainnya ke wilayah atau zona rawan (Tuanakotta, 2011). Akan tetapi, auditor akan selalu berhadapan dengan berbagai risiko selama auditnya berlangsung. Tuanakota juga menyatakan bahwa isu yang dianggap penting dalam penentuan risiko audit lainnya adalah berupa pendapat going concern perusahaan karena dianggap memiliki profil risiko yang tinggi. Isu lain yang dianggap penting adalah kelemahan material dalam pengendalian internal perusahaan karena akan sangat berpengaruh pada kewajaran penyajian laporan keuangan klien. Tingkat risiko ketergantungan pengguna eksternal LK merupakan salah satu faktor saja dalam pertimbangan penentuan tingkat 
risiko audit yang dapat diterima. Karena secara luas hal tersebut termasuk dalam faktor risiko terkait keuangan klien. Fokus auditor terkait dengan pengguna laporan keuangan lebih dibahas dalam konteks risiko perikatan yaitu terkait dengan luasnya pengguna laporan opini audit atas laporan keuangan klien. Jumlah pengguna laporan keuangan yang semakin luas akan meningkatkan risiko perikatan (Tuanakotta, 2011).

3. Pengaruh kemungkinan kesulitan keuangan klien terhadap tingkat risiko audit yang dapat diterima.

Pada pengujian hipotesis yang dilakukan dengan uji-t, diperoleh nilai t hitung $-1,867$ pada tingkat signifikansi 0,065. Nilai ini menunjukkan bahwa kemungkinan kesulitan keuangan bukan merupakan variabel yang mempengaruhi tingkat risiko audit yang dapat diterima.Hasil penelitian menunjukkan adanya arah hubungan negatif antara kedua variabel. Hal ini sejalan dengan penjelasan teoritis bahwa tingkat kemungkinan kesulitan keuangan yang semakin tinggi akan meningkatkan pertimbangan auditor dalam penentuan tingkat risiko audit yang dapat diterima. Seperti yang dijelaskan oleh Messier, auditor harus mendapatkan pemahaman mengenai sasaran dan strategi manajemen serta risiko usaha yang terkait yang mungkin akan menimbulkan salah saji material dalam laporan keuangan. Risiko usaha itu sendiri termasuk faktor eksternal dan internal, tekanan, dan kekuatan yang berhubungan dengan kemmpuan entitas untuk bertahan hidup dan menghasilkan laba (Messier, 2008). Sehingga dalam hal ini kemungkinan kesulitan keuangan klien hanya menjadi salah satu faktor internal dan tekanan yang dialami entitas dan tidak mempengaruhi secara signifikan dalam penetapan tingkat risiko audit yang dapat diterima. Pada praktiknya, kesulitan keuangan klien juga bukan merupakan faktor yang menjadi pertimbangan cukup signifikan bagi auditor dalam penentuan tingkat risiko audit yang dapat diterima. Hal ini terlihat dari hasil pengisian kuisoner penelitian oleh auditor responden yang banyak menjawab netral dan tidak setuju pada butir pertanyaan no 2 mengenai kemungkinan auditor menurunkan tingkat risiko audit yang dapat diterima apabila klien memiliki tingkat likuiditas yang kecil. Hal serupa juga terlihat pada jawaban yang disi responden pada butir pernyataan keempat yaitu mengenai kemungkinan auditor akan menurunkan tingkat risiko jika diketahui bahwa klien telah mengalami penurunan laba atau peningkatan kerugian dalam beberapa tahun terakhir. Sehingga terlihat bahwa pada praktiknya masalah kesulitan keuangan bukan merupakan fokus utama bagi auditor dalam penetapan tingkat risiko audit. 
4. Pengaruh Integritas manajemen terhadap tingkat risiko audit yang dapat diterima.

Pengujian hipotesis keempat menghasilkan nilai $t$ hitung sebesar 5.333 pada tingkat signifikansi 0,000 . Nilai ini menunjukkan bahwa integritas manajemen berpengaruh dalam penetapan tingkat risiko audit yang dapat diterima. Hasil penelitian ini sesuai dengan pendapat dari Love \&Manisero (2011) yang menyatakan bahwa integritas manajemen merupakan elemen kunci dalam pelaksanaan audit yang baik. Tanpa adanya integritas manajemen maka pelaksanaan audit yang berbasis standar pun akan rusak. Hal ini disebabkan karena pelaksanaan audit tidak mencakup secara keseluruhan akuntansi yang terkait dengan kejadian dan peristiwa ekonomis entitas klien. Integritas manajemen merupakan elemen penting yang akan menentukan apakah auditor dapat mengandalkan semua pernyataan lisan maupun tulisan yang diberikan oleh manajemen selama proses audit. Love \& Manisore (2011) lebih lanjut menyatakan bahwa kewajaran penyajian laporan keuangan juga akan sangat tergantung dengan integritas manajemen dalam penyusunan laporan keuangannya. Oleh sebab itu, pengukuran auditor akan integritas manajemen menjadi pertimbangan penting bagi auditor dalam pelaksanaan audit.

Pendapat yang sama disampaikan oleh Tuanakota yang menyatakan bahwa berbeda dengan karyawan, manajemen mempunyai wewenang untuk meniadakan atau override fitur-fitur dalam sistem pengendalian internal. Auditor hanya menerima perusahaan sebagai kliennya, sehingga jika manajemen tidak memiliki integritas maka terdapat potensi besar untuk terjadinya material errors dan material irregularities dalam proses akuntansi dalam menghasilkan laporan keuangan (Tuanakotta, 2011). Hal ini juga didukung oleh agency theory yang menjelaskan tentang conflict of interest yang dapat menyebabkan timbulnya moral hazard dari pihak manajemen untuk melakukan hal-hal yang akan menguntungkan mereka.Butir pernyataan no 7 mengenai tata kelola perusahaan paling banyak mendapatkan respon sangat setuju dan setuju oleh responden terkait dengan pertimbangan penetapan tingkat risiko audit. Selanjutnya butir pernyataan no 2 terkait dengan pengaruh gaya kepemimpinan atasan dengan lingkungan budaya pekerja juga menjadi pertimbangan yang dianggap penting oleh para responden.

Hasil penelitian ini juga sejalan dengan penelitian oleh Kizirian et al (2005) yang menyatakan pentingnya pengukuran integritas manajemen dalam pelaksanaan perencanaan audit dan pendeteksian salah saji. Perencanaan audit sendiri dimulai dengan pengukuran dan penetapan tingkat risiko audit. Informasi mengenai integritas manajemen ini bisa 
diperoleh auditor dari korespondensi dengan auditor terdahulu, atau bertanya kepada pihak lain seperti pejabat bank, pengawas pasar modal, pengacara, notaris, atau mantan anggota Dewan komisaris atau Dewan Direksi. Sumber informasi lain bisa berasal dari media massa mengenai kasus-kasus terkait perusahaan dan manajemen perusahaan.

\section{KESIMPULAN}

Berdasarkan hasil penelitian dan pembahasan yang telah diuraikan, maka dapat diambil kesimpulan sebagai berikut:

1. Risiko perikatan berpengaruh terhadap risiko audit yang dapat diterima yang berarti $\mathrm{H}_{1}$ diterima. Hal ini disebabkan karena auditor sangat berhati-hati dan memberikan perhatian yang besar atas risiko perikatan karena berhubungan dengan eksposur auditor terhadap kerugian finansial dan juga rusaknya nama baik tidak dapat dikendalikan langsung oleh auditor. Hal ini juga didukung dengan jawaban responden yang menganggap penting pemahaman auditor akan kliennya sebagai usaha mengurangi risiko perikatan dan pentingnya sebelum menerima klien baru, KAP harus mencari informasi mengenai calon kliennya seperti posisi klien dalam komunitas bisnis, hubungan dengan KAP sebelumnya, dan sebagainya. Risiko perikatan juga merupakan salah satu titik kritis dalam praktik audit yaitu titik kritis pasca kegiatan audit.

2. Tingkat Ketergantungan Pengguna Eksternal LK terbukti tidak cukup berpengaruh dalam penetapan risiko audit yang dapat diterima. Hal ini didukung oleh hasil pengisian kuisoner yang menunjukkan bahwa besarnya total aset perusahaan bukan merupakan pertimbangan penting bagi auditor dalam penentuan tingkat risiko audit dan auditor tidak memberikan perhatian besar pada luas pengguna laporan keuangan klien serta pada besarnya liabilitas perusahaan. Fokus auditor terkait dengan pengguna laporan keuangan dibahas dalam konteks risiko perikatan yang membahas tentang luasnya pengguna laporan opini audit atas laporan keuangan klien.Jumlah pengguna laporan keuangan yang semakin luas akan meningkatkan risiko perikatan.

3. Kemungkinan Kesulitan Keuangan Klien terbukti tidak cukup berpengaruh terhadap Risiko audit yang dapat diterima. Kemungkinan kesulitan keuangan klien hanya menjadi salah satu faktor internal dan tekanan yang dialami entitas dalam konteks risiko usaha klien yang mencakup faktor eksternal dan internal, tekanan, dan kekuatan yang berhubungan dengan kemmpuan entitas untuk bertahan hidup dan menghasilkan laba. Dalam jawaban kuisoner auditor mayoritas menjawab netral dan 
tidak setuju pada butir peryataan mengenai kemungkinan auditor menurunkan tingkat risiko audit yang dapat diterima apabila klien memiliki tingkat likuiditas yang kecil dan juga pada butir pernyataan mengenai kemungkinan auditor akan menurunkan tingkat risiko jika diketahui bahwa klien telah mengalami penurunan laba atau peningkatan kerugian dalam beberapa tahun terakhir.

4. Integritas Manajemen terbukti berpengaruh terhadap risiko audit yang dapat diterima. Integritas manajemen merupakan elemen kunci dalam pelaksanaan audit yang baik. Tanpa adanya integritas manajemen maka pelaksanaan audit yang berbasis standar pun akan rusak. manajemen mempunyai wewenang untuk meniadakan atau override fitur-fitur dalam sistem pengendalian intern. Manajemen yang tidak memiliki integritas maka menimbulkan potensi besar terjadinya material errors dan material irregularities dalam proses akuntansi dalam menghasilkan laporan keuangan. Oleh karena itu integritas manajemen menjadi pertimbangan signifikan dalam penentuan risiko audit yang dapat diterima.

\section{Keterbatasan}

Penelitian ini memiliki beberapa keterbatasan, yaitu:

1. Jangka waktu pengumpulan data relatif singkat sehingga menyulitkan peneliti untuk memperoleh data dari responden lebih banyak.

2. Sampel yang digunakan dalam penelitian ini kurang luas, karena merupakan populasi terbatas pada auditor yang bekerja di wilayah DKI Jakarta Timur sehingga kurang dapat menggambarkan kondisi umum auditor yang bekerja pada Kantor Akuntan Publik di seluruh wilayah DKI Jakarta.

3. Kurangnya respon dari responden pada level partner untuk benar benar memberikan gambaran tentang penetapan tingkat risiko audit yang dapat diterima.

\section{Saran}

Berdasarkan hasil penelitian, maka saran yang dapat diberikan oleh peneliti adalah sebagai berikut:

1. Bagi Kantor Akuntan Publik diharapkan dapat memberikan perhatian cukup pada tingkat ketergantungan pengguna eksternal LK dan tetap dapat memberikan perhatian cukup terhadap kemungkinan kesulitan klien karena akan sangat berpengaruh dengan going concern perusahaan.

2. Bagi auditor diharapkan dapat meningkatkan kesadaran akan komitmen dan tanggungjawab profesionalnya untuk dapat memberikan hasil audit yang berkualitas dengan menetapkan risiko audit yang dapat diterima pada level yang rendah.

3. Bagi peneliti selanjutnya diharapkan untuk menggunakan 
responden yang lebih luas dan bervariatif dengan menetapkan karakteristik sampel yang diinginkan. Peneliti selanjutnya juga diharapkan dapat mempertimbangkan untuk menambah faktor lain yang dapat mempengaruhi penetapan risiko audit yang dapat diterima sepeti kompleksitas sistem informasi klien.

\section{DAFTAR PUSTAKA}

J. Elder, R. B. (2011). Jasa Auditing and Assurance Services, Pendekatan Terpadu.

Messier, G. d. (2008). Auditing and Assurance Services a Systematic Approach. Jakarta: Salemba Empat .

Tuanakotta, T. M. (2011). Berpikir Kritis dalam Auditing. Jakarta: Salemba Empat. 